\title{
Moringa stenopetala Tree Species Improved Selected Soil Properties and Socio-economic Benefits in Tigray, Northern Ethiopia
}

\author{
Assefa Abay ${ }^{1}$, Emiru Birhane ${ }^{2^{\star}}$, Tewodros Taddesse ${ }^{1}$ and Kiros Meles Hadgu ${ }^{3}$ \\ ${ }^{1}$ Department of Natural Resources Economics and Management, Mekelle University, \\ Post Box: 231, Mekelle, Ethiopia \\ ${ }^{2}$ Department of Land Resources Management and Environmental Protection, Mekelle University, \\ Post Box: 231, Mekelle, Ethiopia \\ ${ }^{3}$ World Agroforestry Centre (ICRAF), ILRI Campus, Post Box: 5689 Addis Ababa, Ethiopia
}

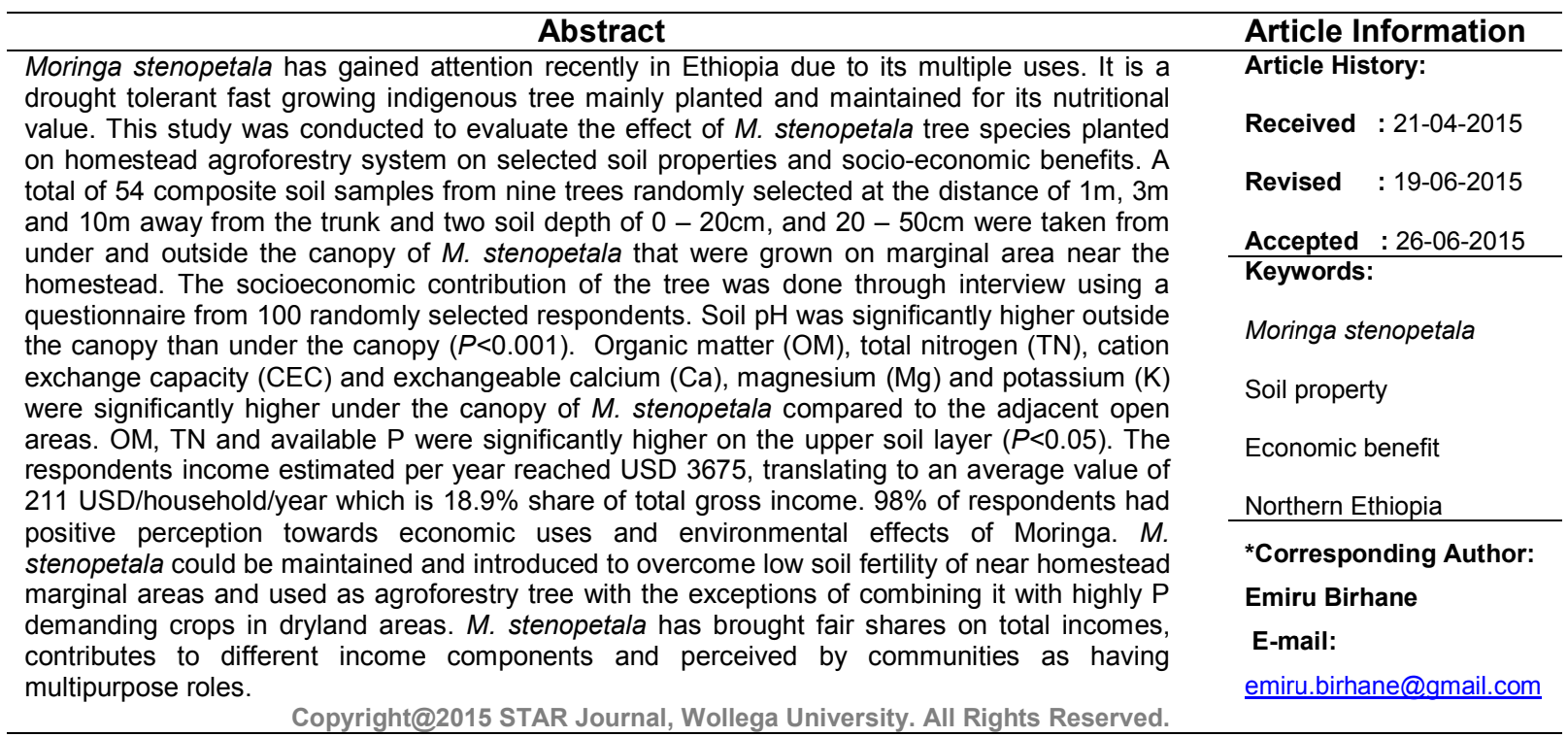

\section{INTRODUCTION}

Design and management of sustainable agroecosystems has important foundations in our understanding of how individual plants grow, develop, and eventually become the plant matter we use, consume and feed to animals as well as capability of the plant sustainable productivity as agroforestry system (Gliessman, 2007). Moringa species is one of the world's most useful plants; it is a fast-growing, much more drought-tolerant and multi-purpose tree that it has been described as a 'miracle tree' (Fuglie, 2003; Amaglo, 2006; Yisehak et al., 2011; Ashfaq et al., 2012). Among the wide range of uses it provides are human food, fuel wood, livestock forage, medicine, dye, water purification, soil and water conservation, quality of cooking oil, green manure and the tree is used as source of income for Moringa growers (Demeulenaere, 2001; Palada and Chang, 2003; Jiru et al., 2006; ECHO, 2009; Morey, 2010; Melesse et al., 2011). M. stenopetala is a tropical plant that belongs to family Moringaceae. The family is represented by a single genus called Moringa. The genus Moringa consists of 14 species to which $M$. stenopetala belongs (Beyene, 2005; Jiru et al., 2006; Aynalem, 2008; Gebregiorgis et al., 2011). Its English names are Africa Moringa tree, Benoil tree, Cabbage tree, Horse-radish tree. Besides, it is also known as Shiferaw in Amharic and Aleko, Aluko and Haleko in the Southern Rift Valley of Ethiopia, in GamoGofa areas (ETFF, 2004; Demeulenaere, 2001; Yisehak et al., 2011).

$M$. oleifera and $M$. stenopetala are the two most common species among the species of the Moringa family, both species have many characteristics in common (Schneemann, 2011). They are commonly grown, but $M$. oleifera is widely cultivated and got research and development attention (Seifu, 2014). M. oleifera differs in growing habit, leaf, flower, and pod characteristics from 
Assefa Abay et alo,

M. stenopetala (Palada and Chang, 2003; Amaglo, 2006). The trunk of $M$. stenopetala is considerably thicker at the base; the tree seems more vigorous, produces larger seeds and leaves than $M$. oleifera; but, $M$. stenopetala leaves taste similar to $M$. oleifera when cooked and milder if tasted raw $(\mathrm{ECHO}, 2007)$. The roots of $M$. oleifera are used as a condiment similar to horseradish while the thick bark of $M$. stenopetala is used; the first flowers of $M$. stenopetala appeared after 2.5 years compared to 2 years for $M$. oleifera raised from seeds and both continues year round after begin to first flower, while $M$. oleifera grown from cuttings start flowering after 8 to 12 months (ECHO, 2007). Bosch (2004) recommended $M$. stenopetala as important multi-purpose tree for semi-arid climates than M. oleifera.

M. stenopetala is often named as African Moringa tree because it is native to southern Ethiopia, North Kenya and Eastern Somalia (Bosch, 2004; Jiru et al., 2006; Gebregiorgis et al., 2011). It is not as widely known as its close relative $M$. oleifera which is native to India, Africa, Arabia, Southeast Asia, South America, and the Pacific and Caribbean Islands (Amaglo, 2006; Jiru et al., 2006; Coppin, 2008). M. stenopetala is a deciduous tree $6-12 \mathrm{~m}$ tall having more or less $60 \mathrm{~cm}$ in diameter at breast height; its crown is strongly branched sometimes with several trunks and its wood is soft (Edwards et al., 2000). Leaves alternate, up to $55 \mathrm{~cm}$ long, 2-3-pinnate, with about 5 pairs of pinnate; stipules absent, but petiole with stipulate glands at base; 3-9 leaflets elliptic to ovate per pinnate, $3.5-6.5 \mathrm{~cm} \times 2-3.5 \mathrm{~cm}$, with stipple-like glands at base of stalk, rounded to connate at base, apex acute, with thickened apiculum; flowers are very fragrant with cream flushed pink sepals, white, pale yellow or yellow-green petals, white filaments and yellow anthers (Bosch, 2004). The ovary is ovoid and densely hairy and its Pods are elongate, reddish with grayish bloom having grooved valves (Beyene, 2005). M. stenopetala is planted either by direct seeding, transplanting, or using hard stem cuttings (Palada and Chang, 2003). M. stenopetala does not have any specific soil requirements, but it prefers a welldrained sandy loam or loamy soils, it tolerates a clay soil except it does not grow on waterlogged or swampy soils and it does not tolerate prolonged flooding; it tolerates a wide range of soil $\mathrm{pH}(5-9)$ from slightly acidic to slightly alkaline (Moges, 2004; ECHO, 2007; Radovich, 2011).

In Ethiopia $M$. stenopetala, is a native tree in arid, semi-arid and semi-humid areas in the altitudinal ranged 1,000 to 1,800 m.a.s.I (Mark, 1998) but it also grows from 390 to about 2200 m.a.s.I in the Southern Rift Valley of Ethiopia (Jiru et al., 2006). It is found widely distributed in Konso, Wolayta, D'irashe, Gamogofa, Sidama, Bale and Borana areas (Aynalem, 2008; Gebregiorgis et al., 2011). It grows well in areas receiving annual rainfall amounts that range from 250 to $1500 \mathrm{~mm}$ and between 25 to $35^{\circ} \mathrm{C}$, can tolerate up to $48^{\circ} \mathrm{C}$ in the shade and survive light frost (Amaglo, 2006). In marginal dry parts of Ethiopia $M$. stenopetala tree is found intercropped with agricultural crops by the Konso people and as on farm tree (homegarden) that supports nearly high population density in South Ethiopia (Jiru et al., 2006). M. stenopetala is a multipurpose tree that is cultivated as agroforestry in Southern Ethiopia; used as living hedges (alley cropping) and windbreaks to reduce the rate of erosion; sometimes the trees are also used to provide partial shade for crops like sorghum; leaves can also be used as a green manure (Demeulenaere, 2001; Beyene, 2005; Schneemann,
Sci. Technol. Arts Res. J., April-June 2015, 4(2): 68-78

2011). In Arba Minch, Ethiopia, the tree is mainly grown in home gardens of up to 0.1 ha with 5-15 trees per garden; other crops usually grown in these gardens are papaya, coffee, banana, cassava, maize, sugar cane, cotton and Capsicum peppers (Schneemann 2011). The choice of vegetables that are adapted to alley cropping is important, such as shade-tolerant leafy vegetables and herbs, since Moringa hedgerows are highly competitive and can reduce yields of companion plants significantly (Palada and Chang 2003; Amaglo, 2006). In Konso areas M. stenopetala is definitely grow in fields, where it is among the most common indigenous species, along with Terminalia brownii, Cordia africana, Croton macrostachyus, various acacias, Carica papaya, Berchemia discolor (Demeulenaere, 2001).

M. stenopetala is described as providing multifunctions in nutrition through decrease hunger; improve health and human nutrition by suppling different food products as all parts of the tree are edible; it also described as Africa's solution to malnutrition and also called mothers' best friend (Fuglie, 2003). A single plant of $M$. stenopetala is able to support a large family for several years (Abuye et al., 2003; Yisehak et al., 2011). In the study area of Alamata district of southern Tigray zone the species is dispersedly planted and introduced at households' backyard (homestead) as agroforestry, in compounds, Farmers Training Center, nursery sites, schools, farm lands and marginal patchy lands. It was distributed for demonstration and promoted as food, feed, commercial product purpose and totally for its socioeconomic significance. The dissemination of $M$. stenopetala in the study area is in its early stage. There had been interests by different stakeholders to the promotion of its socioeconomic significance and nutritional values. However, it didn't receive significant research attention to select, develop as well as potentially evaluate the already introduced $M$. stenopetala plantation in the homesteads and nearby marginal planted areas. Therefore, to support the expansion efforts of its socio-economic significance and understand its interaction with soils we studied the effects of $M$. stenopetela trees on some key soil properties and socio-economic benefits. We assessed effect of planting $M$. stenopetala on key soil properties, benefits to household income, farmer's perception on $M$. stenopetala plantation and its distribution in homestead areas.

\section{MATERIALS AND METHODS}

\section{Study Areas}

Alamata, the study area is located in Southern zone of Tigray Regional State, Ethiopia. It is the south most district of the region and it is one of Southern Tigray zone "Developmental Corridor" district where commercial agriculture is developing. Geographically the district is situated at $12^{0} 25^{\prime} \mathrm{N}$ and $39^{\circ} 33^{\prime} \mathrm{E}$. It is located about 180 $\mathrm{km}$ south of Mekelle the capital city of Tigray region and $600 \mathrm{~km}$ north of Addis Ababa (Figure 1). Altitude of the district ranges between 1450 and 3000 m.a.s.l. Topographically, Alamata is divided into western highland and eastern lowland. There are two zones (urban and rural areas) namely the rural area called Raya Alamata zone and it has 15 tabias and Alamata zone also called Alamata town, comprised of four kebeles (WoARD, 2012). The western highland includes five rural tabias; areas have not $M$. stenopetala trees categorized under the northern highlands of Ethiopia, having an altitude range of 2000 to 3000 m.a.s.l. It is characterized by steep slopes, 
Assefa Abay et alo,

gorges and undulating terrain having scattered flat lands used for grazing livestock and farming. It covers $25 \%$ of the Woreda (WoARD, 2012). The eastern lowland part includes the rest ten rural tabias and Alamata town having M. stenopetala areas is generally plain in topography surrounded by a chain of mountains from the west and
Sci. Technol. Arts Res. J., April-June 2015, 4(2): 68-78

partly north with an altitude ranging from 1450 to 1750 m.a.s.I. It covers $75 \%$ of the Woreda and has plain low landscape (WoARD, 2012). The study sites are located within the Eastern lowland because $M$. stenopetala is found within these eastern lowland plain.

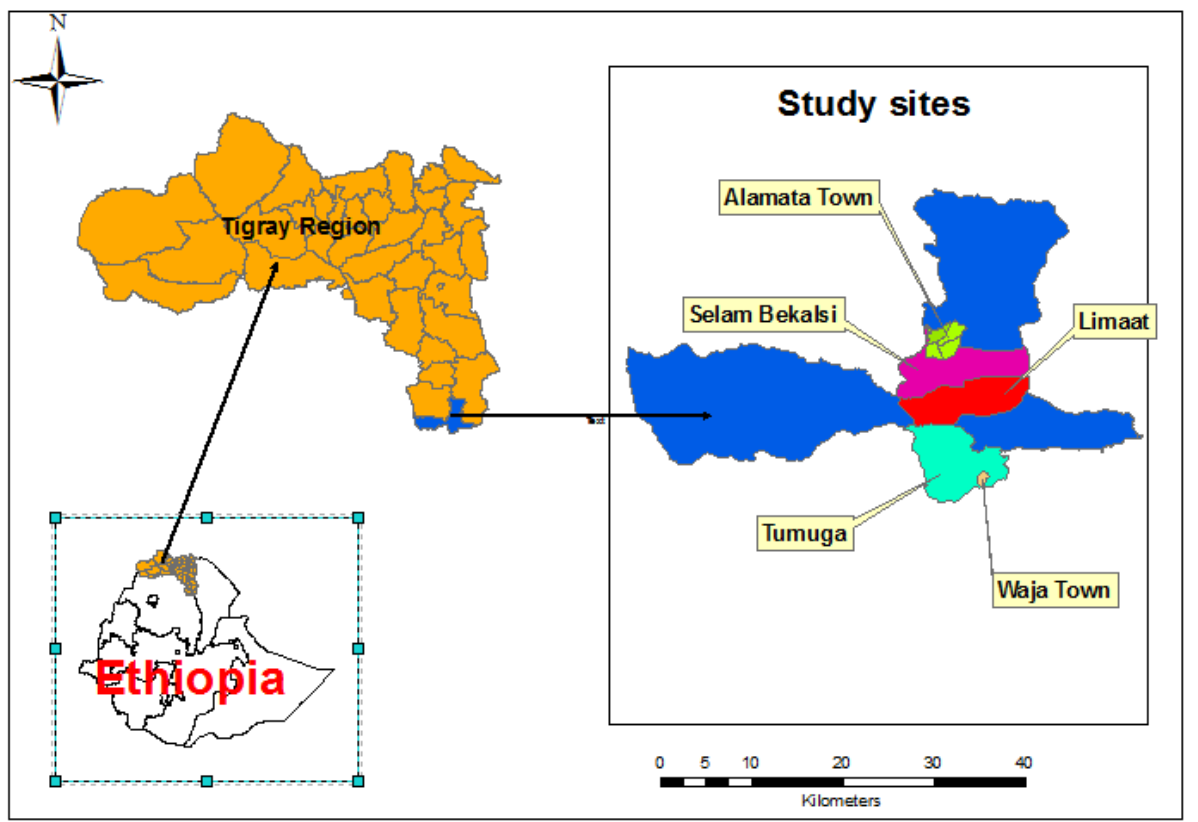

Figure 1: Location map of study areas

The mean annual rainfall and temperature and average monthly rainfall and temperature distribution of the one decade $(2002-2011)$ ranges from 25 to 76.7 $\mathrm{mm} /$ year and $12^{\circ} \mathrm{C}$ to $31^{\circ} \mathrm{C}$, and 10 to $199 \mathrm{~mm} / \mathrm{month}$ and $14^{\circ} \mathrm{C}$ to $33^{\circ} \mathrm{C}$, respectively (Figure 2, TNMA, 2012). It experiences bimodal rainfall, the short rain ranges from February to April and the main rain season from June to early September. Climate of the area differs between the lowland and highland. The study plantation area of eastern lowland sites are characterized by hot to warm sub-moist type of climate where the mean annual rainfall is between 41 to $82 \mathrm{~mm}$ and the mean annual temperature is $18^{\circ} \mathrm{C}$ to $31^{\circ} \mathrm{C}$. A semi-bimodal rainfall pattern with a small peak in April and maximum peak in August dominates this area. The rainfall of the area is highly variable and evapo-transpiration is high (WoARD, 2012). The major soil types are Eutric vertisols, Lithic leptosols (Cambic) and Lithic leptosols (Orthic) (IPMS, 2010). The soil $\mathrm{pH}$ for profiles tested from the valley bottoms indicate that it ranges from 7.4 to 8.5 and is reported to increase with depth (REST, 1998).

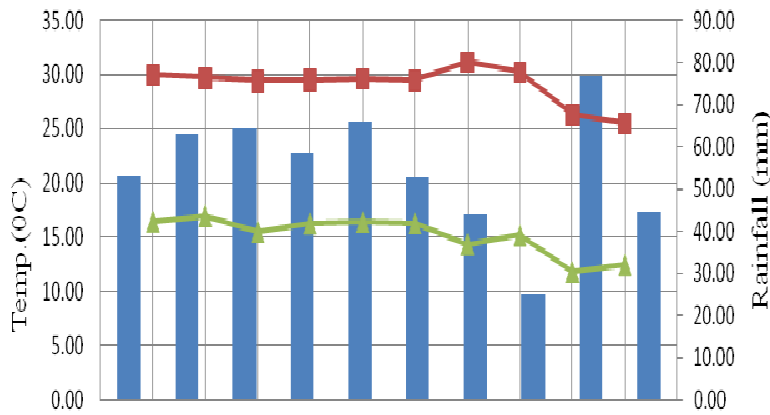

200120022003200420052006200720082009201020112012

Years

\footnotetext{
-Average Annulal Rainfall (mm) - - Average Max. Temp.OC

\pm Average Min. Tetinp. OC
}

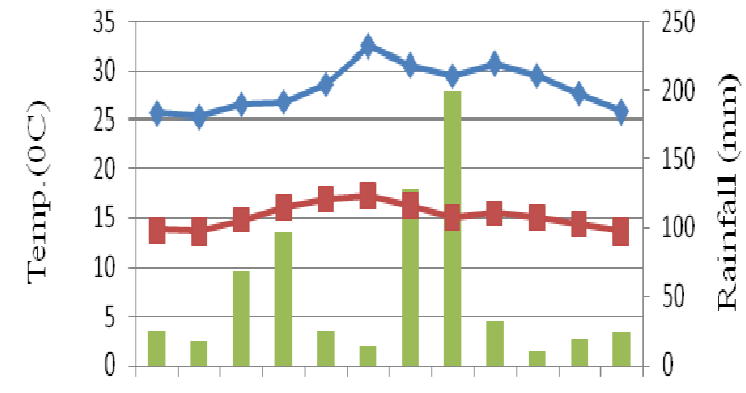

Jan Feb Mar Apr May Jun Jul Aug Sep Oct Nov Dec

\section{Monthis}

$$
\begin{aligned}
& \text { Monthly Total Rainfall (mm) } \bullet \text {-Average Max.Temp. } \\
& \text {-Average Min. Temp. }
\end{aligned}
$$

Figure 2: Annual and monthly rainfall and temperature distribution (2002-2011) of Alamata (TNMA, 2012) 


\section{Study Site selection and Household Selection}

The criteria used to select the study sites for soil sampling and socioeconomic benefits were areas that have $M$. stenopetala in homestead agroforestry system. Discussion with the staff members of WoARD and Tigray Agricultural research Institute (TARI) Alamata branch was conducted for the abundances and distribution of the selected tree in all tabias of the Woreda. After discussion a reconnaissance survey was conducted to obtain an over view on localities that have $M$. stenopetala tree species that were planted in different homesteads and other nearby areas. According to the reconnaissance survey conducted, the distribution of $M$. stenopetala in the Woreda was planted mostly in homesteads and live fence in the rural tabias and urban areas as agroforestry system. M. stenopetala trees found in the eastern lowland plain topography areas of ten rural tabias and Alamata town. Vigorous $M$. stenopetala trees were found in homesteads having up to diameter at breast height of 66 $\mathrm{cm}$ and total height of $9 \mathrm{~m}$. In such areas the $M$. stenopetala trees were found mixed with other species mostly in backyards. The trees in backyards were not selected as communities used to add external inputs like animal dung and related soil fertility enhancing inputs to the homesteads; so these areas were not preferable sites for trees selection in order to assess effects on soil properties. Here, in order to minimize confounding factors the trees for soil sampling were selected from marginal areas of nearby homesteads.

\section{Selection of Trees and Sites for Soil Sampling}

From the reconnaissance survey, nine $M$. stenopetala trees that were grown on marginal lands of nearby homestead areas were selected. The trees were selected randomly from isolated individuals and having nearly similar physiognomic characteristics and planted on similar site conditions, similar altitude, having similar height, $\mathrm{DBH}$, age (all were $\approx 8$ years age) and canopy diameter. Measurements of tree dimensions taken such as: diameter at breast height (DBH) using diameter tape, total tree height using suunto clinometer and crown diameter at crown base using measuring tape. All the nine sampled trees had mean crown length (vertical crown distance) of $72.56 \%$.

Experimental Design and Field Layout: For soil sampling the area under the canopy of each tree was divided into four different radial transects of the tree trunk (Takimoto et al., 2008). The factors studied were depth and distance. Soil sampling were taken at two depths: 0 $20 \mathrm{~cm}$ and $20-50 \mathrm{~cm}$; and at three horizontal distances from the tree trunk: near $1 \mathrm{~m}$ (under canopy), $3 \mathrm{~m}$ (at the boarder of canopy), and $10 \mathrm{~m}$ from the trunk outside the area under canopy (control) at four different directions East, West, North and South around the tree having size $0.5 \mathrm{~m} \times 0.5 \mathrm{~m}$ where composite soil samples were collected.

Soil Sample Collection: A total of 54 composite soil samples were collected from the nine $M$. stenopetala trees from four different directions of each of three distances at two depths. At each distance and depth soils were mixed to obtain a composite sample for the analysis of soil texture, soil $\mathrm{pH}$, soil organic matter (OM), total nitrogen (TN), available phosphorous, exchangeable bases ( $\mathrm{Ca}, \mathrm{Mg}$ and $\mathrm{K}$ ) and Cation Exchange Capacity (CEC) and transported for soil analysis to Mekelle soil laboratory.

\section{Household Selection for Socioeconomic Studies}

Out of the reconnaissance surveyed sites having $M$. stenopetala areas, two rural tabias (Limat and Tumuga) and two towns (Waja-tumuga and Alamata) were selected. The selection of the study areas was purposive based on their potential for $M$. stenopetala and households practice involving the use of the tree as socioeconomic benefits. In each of the four different study areas first population census of $M$. stenopetala growers and number of $\mathrm{M}$. stenopetala of each households were conducted and found a total of 616 households. From the total $M$. stenopetala growing households census conducted, $587(95.3 \%)$ were urban dwellers whereas 29 $(4.7 \%)$ were rural dwellers. After population census had been conducted, from all study sites 100 households were taken using simple random sampling method from the list of growers for the study. For qualitative data collection additional focus group discussion with experts of office of WoARD, Alamata branch of TARI, administration office and local administrators was conducted.

Socio-economic Survey: Data collection was done through interview and observation survey of households sampling from $M$. stenopetala tree growers and focus group discussion with experts of office of WoARD, Alamata branch of Tigray agricultural institute (TARI), administration office and local administrators. Household interview was used based on the selected random sampling procedure of sample households survey from each of the four study areas to address the specific objectives of the socio-economic benefits. Household survey was the main source of information.

\section{Soil Laboratory Analysis}

In the laboratory, the composite soil samples were analyzed in Mekelle soil laboratory for soil texture by using hydrometer method (Gee and Bauder, 1986); soil $\mathrm{pH}$ was measured potential metrically using a digital $\mathrm{pH}$ meter in 1:2.5 soils to water suspension (Jackson, 1973). Organic carbon was determined following the WalkleyBlack method (Walkley-Black, 1934) and OC was converted in to the organic matter by multiplying by a factor 1.724. Total nitrogen was analyzed by Kjeldahl procedure as described by (Ranst et al., 1999); available phosphorus was analyzed by Olsen method (Olsen and Sommers, 1982); Exchangeable $\mathrm{Ca}$ and $\mathrm{Mg}$ were determined by extraction of Ammonium Acetate with titration method while exchangeable $\mathrm{K}$ was determined from the same extraction (Ammonium Acetate) using flame photometer and CEC was determined by Ammonium Acetate method (Schollenberger and Simon, 1945).

\section{Statistical Analysis}

The experiment was laid out with single tree species, three radial/horizontal distance and two soil depths in factorial arrangement with factorial randomized complete block design. Two-way ANOVA was used to test whether or not a significant difference exists for mean soil parameters at $5 \%$ level of significance using the GLM of SAS 9.1 and JMP-5 statistical software's. Treatment means were compared using Fisher's Least Significant Difference (LSD).

The data collected from socio-economic survey were first coded and fed into SPSS 16.0. To assess share of income from $M$. stenopetala on total household income and perceptions of local communities on the tree, data 
Assefa Abay et alo,

were analyzed, compared and contrast using descriptive statistics and $\mathrm{t}$-Test mean comparisons was used among rural and town study areas and how $M$. stenopetala contributes to total household income and different income components such as sales, food own consumption, medicinal value, fodder and fuel wood.

\section{RESULTS AND DISCUSSION}

\section{Effect of $M$. stenopetala Tree on Soil Properties Soil Texture and $\mathrm{pH}$}

The texture at the study sites were sandy loam to loam soils according to USDA textural classification. The sand proportion was $(47.3 \%)$, silt $(34.9 \%)$ and clay $(17.6 \%)$ (Table 1). The soils of the areas were predominantly sandy $(>44.2 \%)$. The clay content in the soil was small $(<20.4 \%)$. The $\mathrm{pH}$ of the study areas ranged from 7.49 to 8.05 . Soil $\mathrm{pH}$ was significantly different for both distance from the tree and soil depth $(P<0.0001)$. The interaction effect between distance from the tree and soil depth was not significant (Table 2). There was a higher $\mathrm{pH}$ in the adjacent open area than under the canopy of $M$. stenopetala tree between the radial distance
Sci. Technol. Arts Res. J., April-June 2015, 4(2): 68-78

from the tree trunk and increased with depth (lower at 0$20 \mathrm{~cm}$ as compared to the $20-50 \mathrm{~cm}$ depth). The slight decrease in alkalinity under the canopy than the open area could be attributed due to break down of litter fall and dead roots from the tree, which means there was higher organic matter (OM) under the canopy and upper soil layer than the open area and subsoil layer, respectively. This more $\mathrm{OM}$ provides resilience (preventing rapid exchange) of $\mathrm{pH}$. The finding of this study is in agreement with other species Bhatia et al., (1998) who observed a significant reduction in soil $\mathrm{pH}$ under the canopies of Prosopis juliflora. Similarly Kahi et al. (2009) reported a significant difference $(P<0.05)$ in $\mathrm{pH}$ between the soils within and outside the canopies of Prosopis juliflora and Acacia tortilis, The $\mathrm{pH}$ was found higher in the open cultivated land than under the canopy areas. Kamara and Haque (1992) reported a significant variation in soil $\mathrm{pH}$ horizontally under $F$. albida tree canopies which is different to the findings of Manjur (2011) under F. albida and $C$. macrostachyus tree species there were no significant differences in soil $\mathrm{pH}$ under the canopies compared to open area and depth differences.

Table 1: Soil texture class (USDA) at different distance from the canopy (1m, under the canopy; $3 \mathrm{~m}$, edge of canopy \& $10 \mathrm{~m}$, outside the canopy), soil depth $(\mathrm{cm})$ of $M$. stenopetala tree

\begin{tabular}{llllll}
\hline Distance & Depth & Sand (\%) & Silt (\%) & Clay (\%) & Soil Texture \\
\hline \multirow{2}{*}{ Total } & $0-20 \mathrm{~cm}$ & 47.9 & 34.85 & 16.85 & Loam \\
& $20-50 \mathrm{~cm}$ & 46.8 & 34.96 & 18.26 & Loam \\
$1 \mathrm{~m}$ & & 49.4 & 34.8 & 15.2 & Loam \\
$3 \mathrm{~m}$ & \multirow{2}{*}{$10 \mathrm{~m}$} & 48.4 & 34.6 & 17 & Loam \\
& & 44.2 & 35.3 & 20.4 & Loam \\
\hline
\end{tabular}

\section{Soil Organic Matter}

Soil organic matter (OM) of the study area ranged from 1.3 to 3.8 falling in to very low OM level. There was a significant difference in soil OM between the radial distance from the tree canopy and soil depth $(P<0.05)$. The interaction effect between distance from the tree and soil depth was not significant (Table 2). The soil OM was higher under the canopy of the tree than outside the canopy of the adjacent open area and showed a decreasing trend with increasing distance from the base of the tree towards the open field $(P<0.0004)$ and decreased with depth $(P<0.006)$. This variation in $\mathrm{OM}$ with distance away from the tree canopy could be due to decompositions of the plant residue: leaf litters fall, elongated pods contained many seeds fall and dead roots from the tree as compared to the adjacent open areas while the source of OM outside the canopy was mostly grass residues. There could be more recent decomposed and accumulated organic matter at the topsoil than subsoil layer as the leaves of trees were not cut for market value for the selected trees found on the marginal lands. Ashfaq et al. (2012) found similar result on $M$. oleifera tree and strongly recommended for Agro-forestry and rangelands of Pakistan to improve organic matter in soil and ultimately to improve the soil fertility. Hiawatha (2010) reported that, $M$. oleifera can grow on harsh and drier soils; it can be used as green manure to improve soil fertility. Yadessa et al. (2001) had reported a significant decrease in OC and OM away from the tree trunk to the open cultivated land on Cordia africana tree. Gindaba et al. (2005) also reported the surface soil OC under both $C$. macrostachyus and $C$. africana tree species was significantly higher $(P<0.05)$ than that at the subsurface.

\section{Total Nitrogen}

Mean total nitrogen (TN) of the study area was 0.11 ranged from 0.07 to 1.14 rate falling into low to very low. TN was significantly different between the distance from the tree trunk and soil depth (Table 2). TN was higher under the canopy of the tree compared to the open area $(P<0.0001)$. There was a decreased in TN with depth, higher at $0-20 \mathrm{~cm}$ as compared to the $20-50 \mathrm{~cm}$ depth $(P<0.003)$. Higher TN under the canopy than the open area could be attributed to higher $\mathrm{OM}$ and nitrogen mineralization under the canopy and upper soil layer. The deep rooted system can operate as a nutrient pump for leached nitrogen from deep soil or slow down leaching. Studies conducted on $M$. oleifera, reported introduction of this plant into a farm can be beneficial for both the owner of the farm and the surrounding ecosystem; the seed cake of $M$. oleifera can be used as a nitrogen-rich plant fertilizer (Foidl et al., 2001). Ashfaq et al., (2012) reported that $M$. oleifera is deep rooted and does not compete with crops for nutritional concerns; it does not have any direct competition with food crops. Palada and Chang (2003) reported that Moringa once established the extensive and deep root system of Moringa is efficient in mining nutrients from the soil.

\section{Available Phosphorus}

Available phosphorus (Av. P) of the study area ranged from 1.34 to 15.98 having mean value $7.7 \mathrm{ppm}$ falling into low to medium level. Available phosphorus was significantly higher at $0-20 \mathrm{~cm}$ as compared to the 20-50 $\mathrm{cm}$ soil depth $(P<0.0001)$. This initial high phosphorus in the upper than sub soil layer could be due to high availability of $\mathrm{OM}$ on the upper soil layer. Available 
Assefa Abay et alo,

phosphorus was higher in the open areas than under the canopies of the tree but, didn't show significant difference (Table 2). However, Palada and Chang (2003) reported Moringa once established the extensive and deep root system of Moringa is efficient in mining nutrients from the soil. Available phosphorus was significantly higher in the
Sci. Technol. Arts Res. J., April-June 2015, 4(2): 68-78

open areas than under the canopies of $A$. tortilis and $P$. juliflora trees in Kenya (Kahi et al., 2009), and Young (1989) also observed low phosphorus in sub-canopy zones and attributed it to being utilized in biological nitrogen fixation by the Rhizobium bacteria

Table 2: The effect of $M$. stenopetala tree on soil pH, Organic carbon (OC \%), Organic Matter (OM \%), Total nitrogen (TN \%) and available phosphorus (ppm) at different distances from the canopy $(1 \mathrm{~m}$, under the canopy; $3 \mathrm{~m}$, edge of canopy and $10 \mathrm{~m}$, outside the canopy) and soil depth (cm)

\begin{tabular}{|c|c|c|c|c|c|c|}
\hline \multirow{3}{*}{ Distance } & \multirow{3}{*}{ Depth } & \multicolumn{5}{|c|}{ Soil Chemical Properties } \\
\hline & & $\mathrm{pH}$ & OC & OM & TN & $\mathbf{P}$ \\
\hline & & \multicolumn{5}{|c|}{ Mean \pm Std. Dev } \\
\hline \multirow[b]{2}{*}{1} & $0-20$ & $7.58 \pm 0.06$ & $1.79 \pm 0.3$ & $3.09 \pm 0.52$ & $0.126 \pm 0.01$ & $9.33 \pm 3.2$ \\
\hline & $20-50$ & $7.86 \pm 0.09$ & $1.51 \pm 0.31$ & $2.61 \pm 0.53$ & $0.109 \pm 0.02$ & $4.86 \pm 3.2$ \\
\hline \multirow[b]{2}{*}{3} & $0-20$ & $7.61 \pm 0.08$ & $1.68 \pm 0.3$ & $2.89 \pm 0.51$ & $0.118 \pm 0.02$ & $9.28 \pm 3.4$ \\
\hline & $20-50$ & $7.86 \pm 0.09$ & $1.38 \pm 0.34$ & $2.39 \pm 0.58$ & $0.108 \pm 0.02$ & $4.65 \pm 3.06$ \\
\hline \multirow[b]{2}{*}{10} & $0-20$ & $7.72 \pm 0.064$ & $1.3 \pm 0.36$ & $2.24 \pm 0.63$ & $0.098 \pm 0.01$ & $11.87 \pm 3.16$ \\
\hline & $20-50$ & $7.95 \pm 0.08$ & $1.12 \pm 0.3$ & $1.92 \pm 0.53$ & $0.085 \pm 0.01$ & $5.97 \pm 3.13$ \\
\hline \multirow[b]{2}{*}{ Total } & $0-20 \mathrm{~cm}$ & $7.64^{\mathrm{b}}$ & $1.59^{\mathrm{a}}$ & $2.74^{\mathrm{a}}$ & $0.114^{\mathrm{a}}$ & $10.16^{\mathrm{a}}$ \\
\hline & $20-50 \mathrm{~cm}$ & $7.89^{a}$ & $1.34^{b}$ & $2.3^{b}$ & $0.101^{b}$ & $5.16^{\mathrm{b}}$ \\
\hline LSD & & 0.0428 & 0.1748 & 0.3013 & 0.0082 & 1.7395 \\
\hline P - Value & & 0.0001 & 0.006 & 0.006 & 0.003 & 0.0001 \\
\hline $1 \mathrm{~m}$ & & $7.72^{b}$ & $1.65^{a}$ & $2.85^{a}$ & $0.117^{a}$ & 7.1 \\
\hline $3 m$ & Total & $7.74^{b}$ & $1.53^{a}$ & $2.64^{a}$ & $0.113^{a}$ & 6.97 \\
\hline $10 \mathrm{~m}$ & & $7.83^{a}$ & $1.21^{b}$ & $2.08^{b}$ & $0.092^{b}$ & 8.92 \\
\hline LSD & & 0.063 & 0.2575 & 0.4439 & 0.0121 & 2.5626 \\
\hline P - Value & & 0.001 & 0.0004 & 0.0004 & 0.001 & 0.1 \\
\hline
\end{tabular}

Cation Exchange Capacity (CEC) and Exchangeable Cations

CEC of the soils was significant for distance from the tree $(P<0.005)$ but not significantly different for both soil depth and their interaction effect. There was a higher value of CEC under the canopy of the tree than the adjacent open fields (Table 3 ). It decreased significantly with increasing distance from the tree trunk. This could be mainly due to high organic matter accumulation under the tree canopies than the open fields. The higher amounts of soil organic matter under the tree canopies may imply that more cations would be released to the soil through mineralization as a result; the amount of negative charges in the soil would be higher. There was no significant different for the soil depth, but was higher value of CEC at $20-50 \mathrm{~cm}$ soil depth than $0-20 \mathrm{~cm}$ soil depth, it increased with increasing soil depth.

Table 3: The effect of $M$. stenopetala tree on soil cation exchange capacity (CEC), Exchangeable Calcium (Ca) Exchangeable Magnesium $(\mathrm{Mg})$ and Exchangeable potassium $(\mathrm{K})$ at different distances from the canopy $(1 \mathrm{~m}$, under the canopy; $3 \mathrm{~m}$, edge of canopy and $10 \mathrm{~m}$, outside the canopy) and soil depth (cm).

\begin{tabular}{|c|c|c|c|c|c|}
\hline \multirow{3}{*}{$\begin{array}{c}\text { Distance } \\
\text { from the } \\
\text { tree }(m)\end{array}$} & \multirow{3}{*}{$\begin{array}{l}\text { Depth of } \\
\text { Soil }(\mathrm{cm})\end{array}$} & \multicolumn{4}{|c|}{ Cations } \\
\hline & & CEC & Exch. Ca & Exch. Mg & Exch. K \\
\hline & & \multicolumn{4}{|c|}{ Mean \pm Std. Dev (Meq/100g soil) } \\
\hline \multirow[b]{2}{*}{1} & $0-20$ & $36.56 \pm 5.04$ & $20.6 \pm 2.45$ & $6.93 \pm 1.08$ & $1.197 \pm 0.48$ \\
\hline & $20-50$ & $37.85 \pm 4.94$ & $21.6 \pm 1.7$ & $7.46 \pm 1.56$ & $0.99 \pm 0.21$ \\
\hline \multirow[b]{2}{*}{3} & $0-20$ & $34.8 \pm 4.22$ & $20.02 \pm 2.28$ & $6.68 \pm 1.24$ & $1.18 \pm 0.49$ \\
\hline & $20-50$ & $35.37 \pm 3.88$ & $20.21 \pm 1.98$ & $6.94 \pm 1.29$ & $0.96 \pm 0.21$ \\
\hline \multirow[b]{2}{*}{10} & $0-20$ & $31.3 \pm 3.69$ & $17.94 \pm 2.16$ & $5.13 \pm 1.36$ & $0.7 \pm 0.43$ \\
\hline & $20-50$ & $32.96 \pm 3.98$ & $19.48 \pm 1.54$ & $5.32 \pm 1.56$ & $0.64 \pm 0.32$ \\
\hline \multirow[b]{2}{*}{ Total } & $0-20$ & 34.22 & 19.52 & 6.25 & 1.03 \\
\hline & $20-50$ & 35.39 & 20.43 & 6.58 & 0.87 \\
\hline LSD & & 2.4059 & 1.1177 & 0.7429 & 0.2044 \\
\hline P - Value & & 0.3 & 0.1 & 0.3 & 0.1 \\
\hline 1 & & $37.2^{a}$ & $21.1^{a}$ & $7.2^{a}$ & $1.095^{a}$ \\
\hline 3 & Total & $35.09^{\mathrm{ab}}$ & $20.12^{\mathrm{ab}}$ & $6.81^{a}$ & $1.072^{\mathrm{a}}$ \\
\hline 10 & & $32.13^{\mathrm{b}}$ & $18.71^{\mathrm{b}}$ & $5.23^{b}$ & $0.67^{\mathrm{D}}$ \\
\hline LSD & & 3.5422 & 1.6466 & 1.0945 & 0.3011 \\
\hline P - Value & & 0.005 & 0.004 & 0.0002 & 0.002 \\
\hline
\end{tabular}

${ }^{*}$ Means with the same letter are not significantly different at $(P<0.05)$ 
Assefa Abay et alo,

The values of three primary exchangeable cations $(\mathrm{Ca}$, $\mathrm{Mg}$ and $\mathrm{K}$ ) were significantly different between distances from the tree $(P<0.05)$. There was higher exchangeable $\mathrm{Ca}, \mathrm{Mg}$ and $\mathrm{K}$ under the canopy of the tree than the adjacent open fields similar to CEC (Table 3). The amounts of cations in the soils significantly decreased as the distance from the tree trunk increased. This could be due to the high accumulation of litter under the tree canopies as the cations would be released when the accumulated litters from the canopies of the trees undergo microbial decomposition followed by mineralization and release of simple products to the soil; and decrease their reduction from leaching or erosion. It was reported that the content of $\mathrm{K}, \mathrm{Ca}$ and $\mathrm{Mg}$ decreased from the top to the lower soil depths and from the closest to the midst and distant positions of the soil under $H$. abyssinica, Senecio gigas and Chamaecytisus palmensis trees (Mekonnen et al., 2009). There was no significant difference showed for soil depth and their interaction effects for all the three exchangeable Cations but gradually increased with increasing depth for $\mathrm{Ca}$ and $\mathrm{Mg}$ where as decreased with increasing soil depth for $\mathrm{K}$ under the canopy of the tree (Table 3).

\section{Homestead Agroforestry Practices and Distribution of M. stenopetala}

The average sizes of homesteads of the households ranged from 0.01 ha to 1 ha; mostly $41 \%$ of the households own from 0.02 ha to 0.0625 ha areas of homesteads in the study areas. Traditionally, in the study areas, the homestead system of agroforestry trees commonly grown as home garden, live fence (boundary planting) and wind breaks. There were different number and types of tree species commonly grown (conserved) mixed together in homesteads based on their uses. About 28 tree species were recorded within the homesteads. Each of the respondents had from 1 - 16 tree species mixed together in their homesteads. These homestead agroforestry trees provide a wide range of uses. The products include food, medicinal value, livestock feed, construction material, fuel wood, farm tools, lumber and cash income for home use and sale. Other services that the trees provide includes boundary marking, windbreaks, live fence, soil erosion control, soil fertility enhancement, beauty and shade.

The distribution of $M$. stenopetala in the study areas was mostly in homesteads and live fence in the rural tabias and urban areas respectively. From the total respondents owned $M$. stenopetala, $95 \%$ had $1-10 \mathrm{M}$. stenopetala plant in their compounds/homesteads; whereas $5 \%$ of them owned 16 - $40 \mathrm{M}$. stenopetala plants. There were a total of 409 trees and on average $4 \mathrm{M}$. stenopetala per household. However, from the total number of trees $135(33 \%)$ were less than one year old
Sci. Technol. Arts Res. J., April-June 2015, 4(2): 68-78

which were not ready for leaf harvest. A total of $274 \mathrm{M}$. stenopetala trees $(2.7 \mathrm{M}$. stenopetala per household) between 2 and 12 years of tree age were ready for leaf harvest. In addition to homesteads, the species is found in the marginal lands, field farmers training center, schools, health centers, compound of different offices and on few farm lands. Higher abundance of M. stenopetala trees were observed in the towns (83\%) than rural tabias (17\%).

\section{Socioeconomic Values of $M$. stenopetala Tree}

There was no significant difference in household characteristics due to age, sex, educational level, household size and marital status between the households in the rural and town of $M$. stenopetala growers. Type of employment showed a significant difference in the income obtained from the tree between the rural and town households (Table 4).

Table 4: Chi-square Tests of sampled households characteristics by rural tabias and towns of study areas

\begin{tabular}{lcc}
\hline Household characteristics & $\begin{array}{c}\text { Chi-square } \\
\text { Value }\end{array}$ & $\begin{array}{c}\boldsymbol{P} \text { - } \\
\text { value }\end{array}$ \\
\hline Age of head of the household & 0.153 & $0.926 \mathrm{~ns}$ \\
Sex & 0.014 & $0.906 \mathrm{~ns}$ \\
Educational status & 8.886 & $0.064 \mathrm{~ns}$ \\
Household size & 2.117 & $0.548 \mathrm{~ns}$ \\
Marital status & 0.016 & $0.999 \mathrm{~ns}$ \\
Type of employment & 12.267 & $0.002^{*}$ \\
\hline Significance level: ${ }^{*}=P<0.05$ significant and ns=not significant \\
\multicolumn{3}{c}{$P>0.05$}
\end{tabular}

Households earned on average 4022.2 Ethiopian Birr/year/household from diversified income components of $M$. stenopetala products (Table 5 ). There was higher income (5013.5 Birr/year/household) in towns whereas 294.8 Birr/year/household in rural tabias. There was significant difference in incomes between households that purposefully include the tree as one source of income and those who didn't $(P<0.000)$. The income of households was $61077,564.5$ and 232.5 Birr/year/household for Moringa growing and selling, off farm and farming workers, respectively (Table 5). Urban households earned better income than the rural households due to a better information access on $M$. stenopetala use for different purposes and accesses to market. The highly significant diference between households that include as one source of income than those didn't might be due to the difference in value addition. The once that depend mainly on the species prepared powder of $M$. stenopetala leaves for market and sale as a source of income to major town such as Alamata (local market), Mekelle (regional market) and to Addis Ababa (national market).

Table 5: Mean comparisons of annual incomes earned in Birr/year/household from $M$. stenopetala among rural and towns based on occupational differences

\begin{tabular}{|c|c|c|c|c|}
\hline \multirow{2}{*}{ Occupation } & \multicolumn{2}{|c|}{ Name of study areas } & \multirow{2}{*}{ Total income earned } & \multirow[t]{2}{*}{ Sig } \\
\hline & Rural tabias & Towns & & \\
\hline Farming & 264.4 & 215.6 & 232.5 & 0.61 \\
\hline No. & 18 & 34 & 52 & \\
\hline Off farm & 476.7 & 571.3 & 564.5 & 0.61 \\
\hline No. & 3 & 39 & 42 & \\
\hline Moringa member (Moringa growing and selling) & & 61077 & 61077 & 0.000 \\
\hline No. & & 6 & 6 & \\
\hline Total & 294.8 & 5013.5 & 4022.6 & \\
\hline No. & 21 & 79 & 100 & \\
\hline
\end{tabular}


Assefa Abay et alo,

The average gross incomes of households earned per year was $25 \%$ from farming, $53.4 \%$ from off farm, $18.9 \%$ from $M$. stenopetala and $2.7 \%$ was from homestead agroforestry trees excluding $M$. stenopetala (Table 6). In the study areas from the total respondents, $87 \%$ of them used $M$. stenopetala as income source, and $13 \%$ didn't. The respondents earned on average 4022.6 Birr/ household/year from $M$. stenopetala and it comprised an average of $18.9 \%$ share of the total annual gross incomes (Table 6). The species perceived by the communities as more valuable than fruit trees due to the higher income contribution to the household. The average income of households' from $M$. stenopetala had significant contribution to the total incomes shares (Table 7). ETFF (2004) and Demeulenaere (2001) reported that, in some parts of southern Ethiopia, especially among the Konso people, the one with many Moringa tree in the garden or on farmland has a higher social status and also
Sci. Technol. Arts Res. J., April-June 2015, 4(2): 68-78

considered rich. $M$. stenopetala used to diversify income; $74 \%$ for direct sales, $41 \%$ for food own consumption, $35 \%$ for medicinal value, $7 \%$ for fodder, $37 \%$ for fuel wood and environmental service (soil conservation, soil fertility improvement, windbreaks, live fence, beauty and shade) values (Table 7 ). It was reported $M$. stenopetala is a multipurpose tree that is cultivated as agroforestry in Southern Ethiopia used for human food, fuel wood, livestock forage, medicine, dye, water purification, green manure and its seeds as soil fertilizer, both leaves and seeds used for oil extraction as well as for environmental service and socio-cultural values (Seifu, 2014). Leaves and seeds are rich in oils and the tree is used as source of income for Moringa growers. The tree is called a 'miracle tree' (Seifu, 2014; Amaglo, 2006; Jiru et al., 2006; Demeulenaere, 2001; Schneemann, 2011) due to its multipurpose uses.

Table 6: Total incomes earned from different sources estimated monetary value

\begin{tabular}{|c|c|c|c|c|c|c|c|c|}
\hline \multirow[t]{2}{*}{$\mathbf{S} / \mathbf{N}$} & \multirow{2}{*}{ Income sources earned } & \multicolumn{2}{|c|}{$\begin{array}{c}\text { No. of } \\
\text { households } \\
\text { income earned }\end{array}$} & \multicolumn{4}{|c|}{$\begin{array}{c}\text { Annual incomes } \\
\text { earned in Birr/year/ } \\
\text { household }\end{array}$} & \multirow[t]{2}{*}{$\%$} \\
\hline & & Yes & No & Min. & Max. & Sum & Mean & \\
\hline 1 & \multirow{4}{*}{$\begin{array}{l}\text { M. stenopetala } \\
\text { Homestead agroforestry trees } \\
\text { (excluding Moringa) } \\
\text { Farming } \\
\text { Off farm/ other sources }\end{array}$} & 87 & 13 & 0 & 69840 & 402260 & 4022.60 & 18.9 \\
\hline 2 & & 30 & 70 & 0 & 18,000 & 56670 & 566.7 & 2.7 \\
\hline 3 & & 78 & 22 & 0 & 65680 & 530535 & 5303.35 & 25 \\
\hline 4 & & 65 & 35 & 0 & 80000 & 1135895 & 11358.95 & 53.4 \\
\hline \multicolumn{2}{|r|}{ Total annual incomes earned } & & & 1100 & 113940 & 2125160 & 21251.60 & \\
\hline
\end{tabular}

M. stenopetala leaves had high market demand and becoming income source for the study areas because the tree is in full leaf throughout the year especially at the end of the dry season when other food sources are typically scarce. M. stenopetala leaves used for local markets sale and leaf powder also marketed as a source of income to the local, regional and national markets. It is growing fast, drought-tolerant and its leaves can cut several times per year. The price of fresh leaves from a single tree vary with location, size of trees, time and awareness of households. Market price of single tree for fresh leaves varied from 30 to 300 Birr per plant and the average price of a single tree to harvest the leaf was 200 Birr per plant. Leaves from a single tree can be harvested on average 3 to 4 times per year for fresh leave product. There were households that harvested less than 3 and more than 4 times per year per single tree for fresh leaf products. $74 \%$ of households used $M$. stenopetala leaves as income source. The average income earned from the sale of leaf was 3649.60 Birr/household/year (Table 6). Leaf productions can be viable economic endeavors to meet the growing population demand by planting in their homesteads with small expenses incurred. Moringa cooperative members found in towns buy fresh leaf products from $M$. stenopetala growers in towns and they collect the leaves from different farming households that maintain the tree in their farming system. The cooperatives prepared powder of $M$. stenopetala leaves for market as a source of income and sale to major towns due to the value chain established by the local authorities since 2010. The Moringa members' market price of $M$. stenopetala leaf powder was 100 Birr per $1 \mathrm{~kg}$. All the Moringa members found in Alamata town were youth females. The tree had great role for females as can be done with less labor and earns fair economic values. The members were first trained on the uses of Moringa as human food, medicinal values and promotion of its commercial product purposes on the processing of Moringa leaves in to different food items for marketing, to create rural -urban linkage source of income.

The tree is used as food in the study area. $41 \%$ of the respondents used $M$. stenopetala leaves as main ingredient of food (Table 8). They had eaten the leaf as vegetables either fresh or dried as raw, cooked like cabbage, cooked with carrot \& potato or made into a powder. The powder can be added to any types of sauce (1-3 teaspoons in each sauce), soups, tea and coffee. Flour is also prepared with rice in the study area. Abuye et al. (2003) and Melesse et al. (2011) reported M. stenopetala has various benefits to Ethiopian subsistence agricultural community as a source of daily diet and local medicinal value and the leaves contain protein, carbohydrate, fat, fiber, minerals $(\mathrm{Na}, \mathrm{K}, \mathrm{P}, \mathrm{Ca}, \mathrm{Fe}$ and $\mathrm{Zn}$ ) and vitamins. Single plant of $M$. stenopetala is able to support a large family for several years (Yisehak et al., 2011). The average estimated value used as human food per household was 158.78 Birr/year (Table 7). The leaves have slightly bitter taste and has not good smell which restrict many people to use. Demeulenaere (2001) reported the criterion adopted for the selection is associated with the taste of leaves; the farmers' favor the less bitter varieties and they use the less disintegrating leaf variety while cooking.

M. stenopetala tree had been used mostly for its nutritional and medicinal values. The leaves used as traditional medicinal values to protect and treat from causing different diseases (Table 7 ). In the study areas $35 \%$ of the respondents used the tree as traditional medicinal values and its average medicinal values was estimated at $170.61 \mathrm{Birr} / \mathrm{household} / \mathrm{year}$. The local communities used the leaves to treat different problems such as; hypertension (27\%), diabetes (3\%), asthma 
Assefa Abay et alo,

(9\%), gastritis (2\%), cold (cough) (31\%), Nephritis (Kulalit) (1\%), Arthritis (Kurtmat) (6\%), Hemorrhoid (Kintarot) (2\%), and malaria (13\%). The chopped leaves are used to treat fungal infection (capotes, corporals, Athletics) wound healing $(4 \%)$. Moringa tree parts such as leaves, flowers, seeds, pods, roots, barks used for traditional medicine and treats for more than 157 different diseases (Hiawatha, 2010). All parts of $M$ oleifera tree have been used in folk medicine practices; its leaves, bark, roots, flowers, pods and seeds has been used for about $41,16,23,8,5$ and 9
Sci. Technol. Arts Res. J., April-June 2015, 4(2): 68-78

types of traditional medicinal use respectively (Fahey 2005; and Rajangam et al. 2001). Local people in Ethiopia used the boiled leaves as tea or chopped and mixed it with water to treat malaria, hypertension, stomach problems, expulsion of retained placenta and in some other problems like asthma and diabetes (Mokonnen and Gessesse, 1998; Fuglie, 2003; Palada and Chang, 2003; Amaglo 2006; Jiru et al., 2006; ECHO 2007; Mekete 2008; Morey 2010; Yisehak et al., 2011; Melesse et al., 2011).

Table 7: Comparison of total income earned Vs different sources in Birr/year/household

\begin{tabular}{llcccc}
\hline Average annual income earned & Mean & $\mathbf{N}$ & Std. Deviation & Sig. \\
\hline \multirow{2}{*}{ Pair 1 } & Homestead AF trees (excluding Moringa) & $5.6670 \mathrm{E} 2$ & 100 & 2422.18 & \\
& Total annual income earned & $2.1252 \mathrm{E} 4$ & 100 & 23629.25 & .033 \\
& Farming & $5.3034 \mathrm{E} 3$ & 100 & 11254.22 & \\
Pair 2 & Total annual income earned & $2.1252 \mathrm{E} 4$ & 100 & 23629.25 & .001 \\
& Off farm & $1.1359 \mathrm{E} 4$ & 100 & 18961.93 & \\
Pair 3 & Total annual income earned & $2.1252 \mathrm{E} 4$ & 100 & 23629.25 & .000 \\
& M. stenopetala & $4.0226 \mathrm{E} 3$ & 100 & 14579.44 & \\
Pair 4 & Total annual income earned & $2.1252 \mathrm{E} 4$ & 100 & 23629.25 & .000 \\
\hline
\end{tabular}

Leaves and pods of Moringa are used for animal fodder. The use of leaves and pods for animal fodder was minor compared to the other contributions (Table 8), $7 \%$ of the respondents used as sheep and goat fodder. The estimated average value used as animal fodder was 8.76 Birr/household/year. It is reported that $M$. stenopetala leaves and pods can be used as cattle, sheep, pigs, and goats fodder. Supplementation of animal feed with Moringa is a viable option for improving the production and productivity of livestock (Abuye et al., 2003; Palada and Chang 2003; Jiru et al., 2006; Gebregiorgis et al., 2011; Yisehak et al., 2011). M. oleifera as livestock feed and fodder is rich in nutrients, which are essential for livestock for weight gain (up to $32 \%$ ) and increase in milk production (up to 43-65\%) and is also rich in iron, potassium, calcium and multivitamins (Mathur, 2006).

M. stenopetala trees had been collected for leaf powder and the leaves cut with its branches and the remaining parts of twigs/branches were dried and had been used for fuel wood. The supplies are small and is often used as a fuel in small quantity (Table 8). From the respondents $37 \%$ used the tree as fire wood source and estimated average value was $34.85 \mathrm{Birr} / \mathrm{household/year.}$ Similarly, studies by Palada and Chang (2003); Jiru et al., (2006) reported that $M$. stenopetala grows rapidly, have softwood that is not particularly suitable for fuel and is often used as a fuel in small quantity in its natural range when other sources are scarce. $M$. stenopetala also provide environmental services such as boundary markers, windbreaks, live fence, soil erosion control, soil fertility enhancement, beauty and shade.

\section{Perception and Knowledge of Communities' towards M. stenopetala}

The leaves and stem (branches) were used as economic values of $M$. stenopetala tree parts (Table 8 ). $87 \%$ the respondents used the leaves for market as a source of cash income, human consumption, medicinal value, animal fodder and $37 \%$ of them used its stem (branches) for fire wood. Most of the communities' were well aware of the uses of $M$. stenopetala tree for its different uses. From the total respondent, $2 \%$ of them had no awareness on economic uses of the plant while $98 \%$ of them had positive perception that the tree has high contribution to their income. They stressed that if people in both rural and urban areas grow $M$. stenopetala in their respective localities, it will play the multiple roles of assisting farmers' income and health and help replenish the ever diminishing forest resource of the areas. According to the focus group discussion and $29 \%$ of the respondents stressed the species is perceived by the communities as more valuable than fruit trees and farmers have started deliberately to plant $M$. stenopetala trees in their homestead and other areas. The perception of the households' is in consistence with ETFF (2004) and Demeulenaere (2001) that state in some parts of southern Ethiopia, especially among the Konso people, the economic status of an individual is closely associated with the number of Moringa trees they have in their backyards. The abundance of Moringa species in the garden or on farmland indicates the social status of the owner among the society.

Table 8: Mean comparison of different uses of $M$. stenopetala, used tree parts and estimated monetary value of the tree parts used per year

\begin{tabular}{|c|c|c|c|c|c|c|c|}
\hline \multirow{2}{*}{ Uses or benefits used } & \multicolumn{2}{|c|}{ No. of households } & \multirow{2}{*}{$\begin{array}{l}\text { Used Moringa } \\
\text { tree parts }\end{array}$} & \multicolumn{4}{|c|}{$\begin{array}{l}\text { Estimated value of used parts } \\
\text { from each benefit in Birr/year }\end{array}$} \\
\hline & Yes & No & & Minimum & Maximum & Sum & Mean \\
\hline Income sold (Market) & 74 & 26 & Leaves & 0 & 60,000 & 364,960 & 3649.60 \\
\hline Human consumption (food) & 41 & 59 & Leaves & 0 & 4,800 & 15,878 & 158.78 \\
\hline Traditional Medicinal value & 35 & 65 & Leaves & 0 & 4,800 & 17,061 & 170.61 \\
\hline Fire wood & 37 & 63 & Stem(wood) & 0 & 250 & 3485 & 34.85 \\
\hline Animal feed (Fodder) & 7 & 93 & Leaves & 0 & 300 & 876 & 8.76 \\
\hline Soil erosion conservation & 16 & 84 & Leaves, pods, roots & & & & \\
\hline Improvement of soil fertility & 14 & 86 & Leaves, pods, roots & & & & \\
\hline Total incomes earned & 87 & 13 & & 30 & 69840 & 402260 & 4022.6 \\
\hline
\end{tabular}




\section{CONCLUSIONS}

M. stenopetala is a plant of homestead agroforestry tree, provide options for sustaining environmental services and provide several socio-economic benefits in the study areas. Soil $\mathrm{pH}$ was significantly lower under the canopy of M. stenopetala tree. Soil OM, TN, CEC, and exchangeable $\mathrm{Ca}, \mathrm{Mg}$ and $\mathrm{K}$ were significantly higher under the canopy compared to the open marginal land and declined with distance from the tree base to open area. $M$. stenopetala is efficient at increasing soil fertility. It enhances and conserves soil organic matter and upgrade the capacity of the soil to supply plant nutrients and helps for sustainable ecosystem. However, available phosphorus was not significant to conclude whether $M$. stenopetala tree can be competitive for phosphorus sensitive crops. M. stenopetala tree leaves cultivated for its different uses in the study areas. $M$. stenopetala can be used as an additional income sources and could improve households' income security. Local people perceive that $M$. stenopetala contributes to household income, conserve and enhance soil fertility, windbreaks, live fence, beauty and shade; and it is a tree with a fast growth, can grow within homesteads that requires little financial investment and management. The leaves of $M$. stenopetala can be stored for long times as powder that increase its shelf life. It is used as source of income for urban unemployed youths and had created employment means for rural and urban Moringa growers and urban processors. $M$. stenopetala leaf production could be viable economic ventures for the growing populations and help reverse soil fertility depletion and can improve agricultural productivity.

\section{Conflict of Interest}

Conflict of interest none declared.

\section{REFERENCES}

Abuye, C., Urga, K., Knapp, H., Selmar, D., Omwega, A. M., Imungi, J.M., Winterhalter, P. (2003). A compositional study of Moringa stenopetala leaves. East Africa Medicinal Journal 80: 247-252

Amaglo, N. (2006). Moringa and other highly nutritious plant resources: Strategies, standard and markets for a better impact on nutrition in Africa. Accra, Ghana.

Ashfaq, M., Basra, S.M.A., Ashfaq, U. (2012). Moringa: A Miracle Plant of Agro-forestry. Journal of Agriculture and Social Science 8: 115-122.

Aynalem, A. E. (2008). Moringa stenopetala seed oil as a potential feedstock for Biodiesel production in Ethiopia. Msc. thesis, Addis Ababa University, Ethiopia.

Bhatia, N. P., Adholeya, A., Sharma, A. (1998). Biomass production and changes in soil productivity during longterm cultivation of Prosopis juliflora (Swartz) DC. Inoculated with mycorrhiza and Rhizobium spp in semiarid wasteland. Biology and Fertility of Soils 26: 208-214.

Beyene, D. (2005). Genetic variation in Moringa stenopetala Germplasm of Ethiopia by using Random Amplified Polymorphic DNA as genetic Marker. Msc. thesis, Addis Ababa University, Ethiopia.

Bosch, C.H. (2004). Moringa stenopetala (Baker f.) Cufod. In: Grubben, G.J.H., Denton, O.A. (Eds), PROTA 2: Vegetables/Legumes. [CD-Rom]. PROTA, Wageningen, Netherlands. <http://database.prota.org/search.htm> (accessed: August 21, 2012).
Coppin, J. (2008). A Study of the Nutritional and Medicinal Values of Moringa oleifera Leaves from Sub-Saharan Africa: Ghana, Rwanda, Senegal and Zambia. PhD Thesis, Rutgers, the State University of New Jersey.

Demeulenaere, E. (2001). Moringa stenopetala, a subsistence resource in the Konso district. Proceedings of the International Workshop Development Potential for Moringa Products, October 29-November 2, 2001, DarEs-Salaam, Tanzania, pp: 2-29.

ECHO. (2007). ECHO Technical Note: The Moringa Tree. USA. www.echonet.org ( accessed 24/04/2015).

ECHO. (2009). Educational Concerns for Hunger Organization (ECHO's) Moringa Technical Note. USA www.echonet.org ( accessed 24/04/2015).

Edwards, S., Mesfin, T., Sebsebe, D., Hedberg, I. (2000). Flora of Ethiopia \& Eritrea, Volume 2, Part 1: Magnoliaceae to Flacourtiaceae. Addis Ababa, Ethiopia.

ETFF. (2004). Ethiopian Tree Foundation Fund. 2004. www.addis.etff.org/moringa-link.html (accessed: June 16, 2014).

Fahey J.W. (2005). Moringa oleifera: A Review of the Medical Evidence for Its Nutritional, Therapeutic, and Prophylactic Properties. Part 1. Trees for Life Journal 1:5.

Foidl, N., Makkar, H.P.S., Becker, K. (2001). The potential of Moringa oleifera for agricultural and industrial uses. Proceedings of the International Workshop Development Potential for Moringa Products, October 29-November 2, 2001, Dar-Es-Salaam, Tanzania, pp: 2-29.

Fuglie, L.J. (2003). The Moringa tree a local solution to malnutrition. Dakar, Senegal.

Gebregiorgis, F.; Negesse, T. and Nurfeta, A. 2011. Feed intake and utilization in sheep fed graded levels of dried Moringa (Moringa stenopetala) leaf as a supplement to Rhodes grass hay. Tropical Animal Health and Production 41: 1-9.

Gee, G.W., Bauder, J.W. (1986). Particle Size Analysis: In Methods of Soil Analysis, part-1 Physical and Mineralogical Methods. Monograph No.9.2nd Edition. American Society of Agronomy, Medison Wiskonsin, USA, pp.383-411

Gindaba, J., Romanov, A., Negash, L. (2005). Trees on farms and their contribution to soil fertility parameters in Badessa, eastern Ethiopia. Biological Fertility Soils 42: 66-71.

Gliessman, S. R. (2007). Agroecology: the ecology of sustainable food systems, $2^{\text {nd }}$ ed. university of California, Santa Cruz, USA.

Hiawatha, B.H. (2010). All Things Moringa. The Story of an Amazing Tree of Life. www.allthingsmoringa.com (accessed: January 09, 2013).

IPMS. (2010). Commercialization of vegetable production in Alamata Woreda, Northern Ethiopia: Processes and Impact. ILRI, Addis Ababa, Ethiopia.

Jackson, M. L. (1973). Soil chemical analysis. Prentice-Hall Private Limited, New Delhi, India.

Jiru, D., Sonder, K., Alemayehu, L., Mekonen, Y, Anjulo, A. (2006). Leaf yield and Nutritive value of Moringa stenopetala and Moringa oleifera Accessions: its potential role in food security in constrained dry farming agroforestry systems. Addis Ababa, Ethiopia.

Kahi, C.H., Ngugi, R. K., Mureith, S.M., Ng"ethe J. C. (2009). The canopy effects of Prosopis juliflora (dc.) and Acacia 


\section{Assefa Abay et alo,}

tortilis (Hayne) trees on herbaceous plants species and soil physico-chemical properties in njemps flats, Kenya. Tropical and Subtropical Agroecosystems 10: 441-449.

Kamara, C.S., Haque, I. (1992). Faidheribia albida and its Effect on Ethiopian Highland Vertisosls. Agro-forestry Systems 18: 17-29.

Manjur, B. (2011). Effects of Scattered F. albida and C. macrostachyus Tree species on key Soil Physicochemical Properties and Grain Yield of Maize (Z.mays): a case study at Umbulo wachio watershed, southern Ethiopia. Msc thesis, Mekelle University, Ethiopia.

Mark, E.O. (1998). Research on applied uses of Moringa stenopetala. FAO Technical Bulletin No. 4. http://www.berfingen.info/akababi/simon.htm. (accessed: April 08, 2015).

Mathur, B. (2006). Moringa for Cattle Fodder and Plant Growth. President, Trees for life. www.treesforlife.org/moringa (accessed: December 08, 2012).

Mekete, E. (2008). Moringa stenopetala seed cake powder: a potential for biogas Production and brewery waste water treatment through Coagulation. Msc thesis Addis Ababa University, Ethiopia.

Mekonnen, K., Glatze, G., Monika Sieghardt, M., Franz, O. (2009). Soil Properties under Selected Homestead Grown Indigenous Tree and Shrub Species in the Highland Areas of Central Ethiopia. East African Journal of Sciences 3: 9-17.

Mekonnen, Y., Gessesse, A. (1998). Documentation on use of Moringa stenopetala and its possible anti Leishmanial and anti fertility effects. Ethiopia Journal of Science 21:287-295.

Melesse, A., Tiruneh, W., Negesse, T. (2011). Effects of feeding Moringa stenopetala leaf meal on nutrient intake and growth performance of Rhode island red chicks under Tropical climate. Tropical and Subtropical Agroecosystems 14: 485- 492.

Moges, Y. (2004). Recommended Agroforestry/Multipurpose Trees for Borana Lowlands / Midlands and their Production Techniques. Sub-report No. 4, FARM Africa/SOS Sahel, Tropical Forestry.

Olsen, S.R., Sommers, L.E. (1982). Phosphorus. In: Page A.L., Miller R.H. (Eds). Methods of Soil Analysis. Part 2. 2nd ed. Agronomy Monograph 9, ASA and SSSA, Madison, WI, pp. 403-430.

Palada, M.C., Chang, L.C. (2003). Suggested Cultural Practices for Moringa, international corporation guide, AVRDC pub \# 03-545. Shanhua, Taiwan.

Radovich, T. (2011). Farm and Forestry Production and Marketing Profile for Moringa ( $M$. oleifera). Specialty Crops for Pacific Island Agroforestry. Permanent Agriculture Resources, Holualoa, Hawai'i. http://agroforestry.net/scps (accessed: Feb 12, 2013).
Sci. Technol. Arts Res. J., April-June 2015, 4(2): 68-78

Rajangam, J., Azahakia, M.R.S., Thangaraj, T., Vijayakumar, A., Muthukrishan, N. (2001). Status of production and utilization of Moringa in Southern India. In: Fuglie, L. J (Eds) "The Miracle Tree/ the Multiple Attributes of Moringa". CTA. USA.

Ranst, V.E., Verloo, M., Demeyer A., Pauwels, J.M. (1999). Manual for the Soil Chemistry and Fertility Laboratory. Belgium. 245p.

REST. (1998). Rehabilitation and Society of Tigray: Feasibility Study report, for the Raya Valley Agricultural Development. Volume III, Agriculture. Mekelle, Ethiopia.

Schneemann, J. (2011). Moringa (stenopetala) production and use for water purification in Ethiopia. Fair and sustainable advisory service, Utrecht, The Netherlands.

Schollenberger, C. J., Simon, H.R. (1945). Determination of exchange capacity and exchangeable bases in soilsammonium acetate method. Soil Science 59: 13-24.

Seifu, E. (2014). Actual and Potential Applications of Moringa stenopetala, Underutilized Indigenous Vegetable of Southern Ethiopia: A review. International Journal of Agricultural and Food Research 3: 8-19.

Takimoto, A., Nair, P.K. R., Nair, V. D. (2008). Carbon stock and sequestration potential of traditional and improved agroforestry systems in the West African Sahel. Agriculture, Ecosystems \& Environment 125: 159-166.

TNMA. (2012). Tigray National Meteorological Agency. Mekelle, Ethiopia.

Walkley, A., Black, C.A. (1934). An examination of degtjareff method for determining soil organic matter and proposed modification of the Chromic and Titration method. Soil Science 37: 29-38.

WoARD. (2012). Woreda Office of agriculture and rural development. Alamata, Tigray, Ethiopia.

Yadessa, A., Itanna, F., Olsson M. (2001). Contribution of Indigenous Trees to Soil Properties: The Case of Scattered Trees of Cordia africana Lam. in Croplands of Western Oromia. Ethiopian Journal of Natural Resource 3: $245-270$.

Yisehak, K., Solomon, M., Tadelle, M. (2011). Contribution of Moringa (Moringa stenopetala, Bac.), a Highly Nutritious Vegetable Tree, for Food Security in South Ethiopia: A Review. Asian Journal of Applied Sciences 4: 477-488.

Young, A.1989. Agroforestry for Soil Conservation. ICRAF, Nairobi and CAB International, Wallingford, UK. P44. 